The Geographical Journal of Nepal

Vol. 10: 121-140, 2017

Central Department of Geography,

Tribhuvan University, Kathmandu, Nepal

\title{
Humanistic Geography: How it blends with human geography through methodology
}

\author{
Kanhaiya Sapkota \\ Central Department of Geography, Tribhuvan University, Kirtipur, Kathmandu, Nepal \\ E-mail: kanhaiya.sapkota@gmail.com
}

Humanistic geography is a genre of geography born in late 1960s. A series of theories came out which criticize the knowledge system of logical positivism. The philosophical fundaments of humanistic geography are existentialism and phenomenology. Yi-fu Tuan, Edward Relph, Anne Buttimer, David Ley, Marvyn Samuels and Nicholas Entrikin are the leaders of humanistic geography. Yi-fu Tuan published the first article about humanistic geography, which was collected in Human Geography (1976). The focus of humanistic geography is on people and their condition. However, in different geographic traditions, humanistic geography is often criticized for its weak methodology. I argue humanistic philosophy, can provide a sound epistemologicalframework in which to organize and strengthen this methodology in human geography research. The topics of geographical knowledge, territory and place, crowding and privacy, livelihood and economics, and religion are briefly noted from the humanistic perspective. The basic approach to these topics is by way of human experience, knowledge, and awareness. The application of this approach is emerging in the Nepalese context, however for long time Nepalese geographers followed the Western Eurocentric view and appear to be content in following western notions and ignored understanding our own social and cultural aspects/landscapes that enrich our knowledge of geography. The researcher claims that there is a need to rethink our research practices towards better understanding of the world with austerity of philosophical and methodological consistency.

Keywords: Humanistic approach; methodology; epistemology; ontology; sense of place; landscape 


\section{Introduction}

Humanistic geography reflects upon geographical phenomena with the ultimate purpose of achieving a better understanding of man and his condition (Tuan, 1976). It belongs with the humanities and the social sciences to the extent that they all share the hope of providing an accurate picture of the human world. What is the nature of the human world? The humanities gain insight into it by focusing on what man does supremely well in the arts and in logical thought. The social sciences acquire knowledge of the human world by examining social institutions, which can be viewed both as examples of human inventiveness and as forces limiting the free activity of individuals. Humanistic geography achieves an understanding of the human world by studying people's relations with nature, their geographical behavior as well as their feelings and ideas in regard to space and place (Tuan, 1976). Relations with nature and geographical behavior are, however, also the concern of other geographers. For example, a physical geographer examines the biophysical environment and a regional analyst studies the "laws of spatial interaction." What can the humanist geographer contribute? The question presupposes that we know the meaning of humanism and of the humanistic perspective.

For geography, the 1960s was a decade of methodological innovation and development. Quantification and the evolution of 'spatial science' required a better of new techniques whose development was only tacitly attributed to an underlying philosophy of Comte or logical positivism. However, by 1973, David Harvey had carefully distinguished social and moral philosophy from the philosophy of science; and now the eager recipient of a wide range of philosophical innovations.

The humanist approach in geography developed as a criticism against positivism and quantitative revolution in geography (Ley \& Samuels, 1978). It developed as a result of dissatisfaction with the mechanistic models of spatial science developed during the quantitative revolution. The basic objection of humanists against quantitative revolution is that its tools and assumptions do not adequately explain the human world and human issues, especially those relating to social institutions, attitudes, morals, customs, traditions and aesthetics. These concerns have framed the emergence of geography's 'new humanism' and it most obvious weaknesses is methodological. It is therefore in response to Johnston's largely unanswered changes of 'much preaching and little practice' (Johnston, 1979, p. 138) and then discussed on contemporary research ideas in a phenomenological or existential vine. It addresses the two most popular humanistic philosophies which rely in practice on observational and experimental strategies. Since its inception, humanistic geography has often been contested as a "real" discipline. 
Sometimes used interchangeably with the concept of humanism because of its focus on the human in all its forms (e.g., agency, awareness, consciousness, creativity, etc.), humanistic geography focuses on products of human activity. Humanistic geography ${ }^{1}$ can also be seen as a way to understand those events considered valuable and meaningful to humans. Although usually seen as a specifically human geography pursuit, as aphilosopher, author, and geographer Yi-Fu Tuan alludes, it can also play a role in physical geography. This new physical geography critique notwithstanding, humanistic geography is usually historically equated with the French School of Human Geography such as the writings by Paul Vidal de la Blache along with Neo-Kantianism and Robert E. Park's Chicago School pragmatism, while also focusing on the sense of place and the individual's interpretation of place although "people" and "humans" also collectively fall under its umbrella.

Humanistic geography is a conceptual perspective which claiming that a comprehensive understanding of human-environment relationships must consider individual and group experiences and meanings of space ${ }^{2}$, place $^{3}$, landscape ${ }^{4}$, region ${ }^{5}$, mobility, and related geographic phenomena (Johnston, 1979). The basic feature of humanistic approaches is their focus on man as a thinking being, as a human, rather than as a dehumanised responder to stimuli in some mechanical way, which is how some feel the man is presented in the positivist and structuralist social sciences (Johnston, 1984). Partly propelled by 1960s research in behavioural geography and environmental perception, humanistic geography incorporated a wide range of philosophical approaches that included phenomenology, existentialism, idealism,pragmatism, grounded theory, and symbolic interactionism (Ley \& Samuels, 1978). In the meantime it is also a claim for human geography with the human being at its very centre, a people's geography and about the real people for the people's development as human being for all.

One of the first geographers to attract a wide audience with his advocacy of a humanistic approach was Kirk in 1951. But, it was Yi-Fu Tuan (1976) who powerfully argued for humanistic geography. He defined the approach to the geographic study of human beings'experiences and understandings of space, place, and the natural world. Other geographers most commonly associated with humanistic geography in the early days included Edmunds Bunkse, Anne Buttimer, James Duncan, J. Nicholas Entrikin, David Ley, David Lowenthal, Douglas C. D. Pocock, J. Douglas Porteous, Edward Relph, Graham Rowles, Robert David Sack, Marwyn Samuels, David Seamon, and John Western (Pocock, 1983). In fact, humanistic geography is a perspective that discloses the complexity and ambiguity of relations between man and environment or people and place. Consequently, humanistic geography achieves an understanding of the human 
world by studying people's relation with nature, their behaviour as well as their feelings and ideas in regard to space and place.

Ley and Samuels (1978, p. 50) identify three building blocks of humanistic geography as anthropocentrism, inter-subjectivity, and the concept of place. This viewposits that requires acquires the acquisition of knowledge is an experimental process and it demands that there are no essences or absolutes existing independently of the observer. Therefore, it implies that the only authentic means of appreciation the world is through direct confrontation with it.

The main aim of this paper is to make a discourse on humanistic methods on contemporary human/social geography. For this purpose, I have reviewed a number of literature on humanistic approach, humanism, humanistic geography, and related philosophical debates and discourses on humanistic geography and its methodology used in the contemporary disciplinary practice of geography.

\section{Humanistic geography and the sense of place}

In geographical term sense of place is an individual awareness of the 'spirit' or identity of place. It may be related to physical properties (landscape, urban history), to practical layout and organization (traffic links, location of services), social relations (family, friends) and roots (personal history at this location) ${ }^{6}$. Because it focuses on the individual as well as people in general, sense of place lies at the heart of humanistic geography. Gaining an understanding of how people interact with their environment (physical and cultural), represents a powerful tool in the humanistic geography arsenal. Indeed, of all humanistic geography traits, discovering your ownor another person's or other people'ssense of place remain paramount. Sense of place studies often incorporate behavioural geography and environmental perception in their endeavours. However, these subfields are only tools for exploring the vast literature available relating to sense of place. Owing to its focus on humanistic geography, most of the bibliographies included in this section come from geography as a discipline. Sense of place, however, has strong ties to history, philosophy, psychology, sociology, landscape studies, and anthropology. Although these fields may not openly call their works "humanistic geography," these can and do incorporate and utilise many of its core tenets; the chief among them being an individual's perspective. For example, Edward S. Casey, a philosopher, completeda massive project (Casey, 2009) that attempted in three volumes to re-conceptualize evolving connections among space, place, and individuals, demonstrating the immense power even the concept of place can have. On the otherhand, Cresswell (2004) offers 
readers a concise introduction to the concept of place, utilising many excerpts from leading scholars of place related research, with the majority coming from the discipline of geography, whereas Feld and Basso (1996) offers a very good representation of humanistic geography elements as portrayed from outside the discipline. J. B. Jackson (1995) is perhaps the forefather of modern landscape studies thought and practice and is responsible for bringing the individual experience and sense of place to the masses with highly readable topics and accessible themes. Malpas (1999) acknowledges place as a considerably multifaceted structure but one that is cohesive, fused together with other components that surround and/or help to create place: space, time, subjectivity, and objectivity. Tuan (1991) takes a different route, provocatively discussing how language can lead to experiencing a greater sense of place, and the earlier Tuan (1974) entertains the idea that our surroundings and ethics are important in helping us to understand our own place.

\section{Conceptual and methodological themes of humanistic approach}

Humanistic geography is a perspective which emerged in a particular intellectual context as a reaction to a human geography that had been reduced to the abstract study of space and structures. As such the humanistic perspective has revived earlier geographic traditions which treated human values and intentionality more seriously. It has fortified such traditions by giving them a more critical and philosophically and theoretically informed orientation. The aim is to integrate the humanities and the social sciences building upon the empirical and literary strengths of Vidal de la Blache and Sauer's geography to the scholarship of social theory and the philosophy of science, as well as to the historical context of an advanced and urbanized industrial society.

Major priorities within this work include firstly a more penetrating analysis of culture itself, and particularly the dominant culture of our times, the culture of consumption. The lack of theoretical treatment of consumption in geography has been as notable as the over commitment to theories of production, but there are now several useful starting points in social science for the development of a geography of consumption (Hirsch, 1977; Diggins, 1977; Leiss, 1978). Secondly, associated with this is the greater attention to the semiotics of landscape, the interactions between place, identity, and social context (Godkin, 1977; Duncan, 1978; Rubin, 1979; Harvey, 1979). Thirdly, the need to clarify the place and nature theories of power within a humanistic perspective and this is a major problem within social theory and is unlikely to be easily resolved within human geography. To date, much of the humanistic writing has followed an implicit Weberian line, akin to the managerial position in urban geography which 
stresses the role of institutional (especially government) decision-makers (Saunders, 1979; Ley, 1980 ). These connections need to be examined more explicitly, and it is likely that they will be joined by alternative materialist positions centered about the views of culture and society found in the eclectic writings of Raymond Williams (1977) and E.P. Thompson (1978).

Scientific approaches like positivism, empiricism, and quantification tend to minimize the role of human awareness and knowledge. Humanistic geography, by contrast, especially tries to understand how geographical activities and phenomena reveal the quality of human awareness. Humanistic geography does not consider the human being as an 'economic man. In this regards, the profounder of humanistic geography, Yi- Fu-Tuan (1976) explored five themes of general interest to geographers, namely: (i) geographical knowledge (personal geographies), (ii) territory and place, (iii) crowding and privacy, (iv) livelihood and economics, and (v) religion. However, broadly, one can identify four central conceptual and methodological themes relating to humanistic geography as it developed:

i. Humanistic geographers understood human life and experience to be a dynamic, multivalent structure that incorporates bodily, sensory, emotional, attitudinal, cognitive, and transpersonal dimensions. Humanistic researchers argued that a comprehensive human geography must describe these many dimensions; understand what they contribute to the environmental experience, action, and meaning; and seek out integrated frameworks identifying how these many dimensions relate and interact in supportive and undermining ways. For example, Edward Relph (1976) delineated a spectrum of spatial experience that ranged from the instinctive, bodily, and immediate; to the cerebral, ideal, and intangible. He probed how the experience of space differs from the experience of place and contended that space becomes a place when it gathers human meanings, actions, and identity environmentally and temporally. Similarly, Tuan (1974) delineated a conceptual structure of environmental attitudes and values by consolidating similarities and differences in the ways that human beings respond to their geographical worlds physiologically, psychologically, socially, and culturally. He concluded that every person is, simultaneously a biological being, a social being, and a unique individual. He demonstrated how environmental perceptions, attitudes, and values arise from and contribute to all three aspects of human being.

ii. Humanistic geographers emphasized that much of human experience is opaque, ineffable, or beyond taken-for-granted awareness. To identify and describe these less 
accessible aspects of human life, humanistic geographers largely turned away from the conventional scientific method that required tangible, measurable phenomena explicated and correlated mathematically and statistically. Instead, humanistic geographers turned toward ontological perspectives that accepted a much wider range of experience and presence. They drew on epistemological perspectives ${ }^{7}$ that sought to be open to phenomena and to accept all aspects of their constitution. The aim was an empathetic, wider-ranging mode of discovery whereby the phenomenon was given time and space to present itself. The emphasis was on "methodologies of engagement" that allowed researchers to encounter and understand the worlds and experiences of their subjects carefully, accurately, and comprehensively. In working toward a more intimate encounter with the phenomenon under study, some humanistic geographers used directed intuition and self-reflective explication; others carefully studied real-world situations, for example, a specific urban neighborhood or a small number of individuals asked to describe their environmental experiences and actions as accurately and as thoroughly as possible.

iii. Many humanistic geographers argued that, as much as possible, the evidence, general principles, and understandings of humanistic geography should arise from self-knowledge grounded in researchers' firsthand experiences. Research should work toward a forthright engagement with the experiences of others, whether those "others" are people, places, landscapes, elements of nature, aspects of the human-made environment, or other sentient beings. Humanistic geographers called into question conventional empirical research that defined the topic of research in objectivist fashion as a thing or situation separate from and unrelated to the life or experience of the researcher. Humanistic geographers argued that, by understanding the significance of environmental and geographical experiences in their own lives, individuals might act more responsibly and generously toward other human beings and toward the places and environments that one inhabits or knows (Tuan, 1976). In this regard, Edward Relph (1981) advocated for an environmental humility - a way of engaging with the world whereby things, places, landscapes, people, and other living beings are all respected just for being what they are and, therefore, are thoughtfully cared for and intentionally protected.

iv. Broadly, humanistic geographers grounded their work in two complementary research models, the first of which can be identified as explications of experience; and the second, as interpretations of social worlds. Explications of experience were most often associated with "place studies" and represented by such geographers as 
Anne Buttimer, Douglas C. D. Pocock, Edward Relph, David Seamon, and Yi-Fu Tuan.

Much of the above mentioned work was grounded in phenomenology and, for its place interpretations, drew on a wide range of descriptive sources that included firstperson experience, philosophical argument, archival reports, accounts from imaginative literature, and experiential evidence from photography, film, and other artistic media. Typically, this work emphasized lived commonalities in relation to environmental and place experience, though these humanistic researchers also asked how those commonalities varied in terms of individual and group differences. In the 1980s and 1990s, this work wascriticized as essentialist - claiming generalizable, universal structures such as "place" and "home" and largely ignoring lived variations grounded in social, cultural, and historical factors (Cresswell, 2013).

The second research model for humanistic geography - interpretations of social worlds - as represented by the work of such geographers as James Duncan, David Ley, Marwyn Samuels, Susan Smith, Graham Rowles, and John Western. This work incorporated a wider range of philosophical traditions than experiential explication and included pragmatism, grounded theory, symbolic interactionism, post-structuralism, and Marxist perspectives. Typically, this research was grounded empirically in a specific place or social situation -for example, David Ley's work on inner-city subcultures, housing, and gentrification; John Western's documentation of the impact of apartheid on Cape Town, South Africa; or Graham Rowles's research on the everyday environmental and place experiences of American elderly populations. These researchers interpreted place and related geographical phenomena as a "social construction" arising from purposeful actions of people-in-place. Place was interpreted as a negotiated reality via which people facilitated places, which in turn facilitated the lives of people associated with those places. In the 1980s and 1990s, this "social-constructionist" approach to place became one significant bridge to post-structuralist thinking and the "new cultural geography” (Adams, Hoelscher, \& Till, 2001; Cloke, Philo, \& Sadler, 1991).

Therefore, methodologically, the emphasis on subjectivity leads humanism to be more qualitative and intuitive than either positivism or structuralism. But subjective meanings are interpreted as logically and as rigorously as possible (Subedi, 1993). Generalization is analytic induction and historical reconstruction, based on methods that are eclectic and largely personally selected. Data may be macro and micro but a focus on the community is reflected in an analytical concern with the meso or intermediate level. 
Kanhaiya Sapkota / The Geographical Journal of Nepal Vol. 10: 121-140, 2017

To improve understanding and interpretation a range of sources from archival records through field work or oral history and personal testimony is utilized (Subedi, 1993).

In humanistic geography, as discussed above, central importance is given to the actor's (man's) definition and behavior for examining the social world. The researcher needs to discover the actor's definition of the situation, namely, his or her perception and interpretation of reality and how these relate to behavior. A succinct example of this research in Nepal is that of Subedi (1993) where he interprets forms and meanings of territorial mobility in a rural context of Nepal. In other words, the researcher must be able to see the world as the actor sees it.

\section{Methodological strengths of humanistic approach}

Several years ago David Harvey maintained that it was absolutely vital for any serious investigation into "explanation in geography" to distinguish between philosophy and methodology (Harvey, 1969). The philosophy engages into the issues of belief, so he argued, while methodology dealt strictly with logical procedures; and that methodology, did not necessarily entail, philosophy. That argument, itself a philosophical position derived of logical positivism, has no salience in a humanistic epistemology. On the contrary, even as one may distinguish between the "how" and "why" of inquiry, the central methodological demand of a humanistic geography is to assure the coincidence of method and philosophy. The "means" of analysis, in short, are intimately tied to the "meaning of analysis." Methodology is but a further, if sometimes more specialized, branch of epistemology.

Most if not all of the early complaints leveled against positivist geographies on the part of humanists have been aimed to decry the inappropriateness of certain methods, especially that of quantitative reductionism. In fact, one can argue that positivist methods are appropriate to a thoroughly positivist philosophy of man but that an alternative view of the human condition requires its own method. Phrased differently, a humanistic geography requires an appropriate methodology. The question remains, however, Just what sort of methodology could fulfill the manifold epistemic demands of humanism? In one sense, of course, a humanistic methodology intends the rejection of abstract, statistical, and aggregate measures of the human subject, emphasizing instead a more particularistic, concrete, or highly empirical mode of inquiry. Empiricism and often radical empiricism are hallmarks of an approach that demands greater attention to the subjective roots of man's place, to the insider's perception. Methodologies appropriate for such research are particularly methodologies of encounter, requiring field work; these 
would include observation, participant observation, the use of unobtrusive indicators, and various forms of interviewing (Lofland, 1971). Each of these is a method designed to maintain rather than eliminate the richness and variety of experience. They have been challenged on occasion as being overly subjective, though it is not apparent why a method retaining the diversity of real world places should be more subjective than research referred to sterile or abstracted settings with an impoverished conceptualization of experience. Too much social science research conducted under idealized or laboratory conditions with pretensions of precision can be little more than speculative. In such work subjectivity is not banished, as is claimed, but rather it is the often unrecognized subjectivity of the theorist that is projected into the research design and the research results, in place of the humanist's quest for the subjectivity of the actor in the social world. Alfred Schutz has commented eloquently on the fallacy of social research abstracted from its proper contexts, which "consists in the substitution of a fictional world for social reality by promulgating methodological principles as appropriate for the social sciences which, though proved true in other fields, prove a failure in the realm of inter-subjectivity" (Schutz, 1970).

But field work is only a first step in a humanistic method, to be followed by reflection - interpretation and understanding. The method of verstehen is usually conceived of as the attempt to recapture the subjective meanings of experiences and situations; but, as Weber himself asserted, understanding must go beyond a narrow definition of verstehen to consider the broader contexts within which actions unfold. Useful here is the notion of several levels of meaning to a cultural act, acts that might well, of course, include the construction of landscapes. Most superficially there is the objective or functional meaning of an action; secondly, its expressive meaning, that intended by the actor; and, thirdly, the documentary meaning, that reflective of the broader currents of the time and the place (Mannheim, 1952). The documentary meaning reveals influences and contexts beyond the actor himself, indeed, commonly contexts of which he is unaware despite their impact upon him (Schutz, 1970). For a full interpretation, an understanding of these influences is necessary. The researcher cannot rest content with the actors' own definition of their situation but must immerse himself in a place and a time to uncover the relevant factors at work. For this purpose, a variety of other sources may be consulted, including archival material, literary works, government and other organizational documents, and even statistical data. Whenever direct field contact with a problem is limited, as with historical research, or where access is restricted, as it might be in an investigation of organizations, then interpretation and understanding must rely more heavily on such sources. 
Humanistic geography, especially tries to understand how geographical activities and phenomena reveal the quality of human awareness. The methodology of humanists is characterized by a self-conscious drive to connect with that special body of knowledge, reflection and substance about human experience and human expression, about what it means to be a human being on this earth, namely, the humanities. Similarly, its methods are essentially those of literary criticism, aesthetics and art history. It is essentially based on hermeneutics (the theory of interpretation and clarification of meanings). Its interest is the recovery of place and the iconography (the description and interpretation of landscape to disclose their symbolic meanings), of the landscape. In other words, the interpretation of the landscape as a carrier and repository of symbolic meaning, widening the traditional definitions of iconography the study, description, cataloguing and collective representation of portraiture as revealing of the prevailing aesthetic of an age to include the landscape specifically.

Finally, methodology in humanistic geography lays emphasis on participant observation, interviewing, focus groups discussion, filmed approaches and logical inferences, rather than statistical and quantitative techniques for establishing a correlation between people and place (environment). It is also a philosophy which seeks to disclose the world as it shows before the scientific inquiry, as that which is pre-given and presupposed by the sciences. Humanists argue that 'objectification' is never the simple exercise which conventional forms of science assume them to be.

\section{Criticisms of humanistic geography}

Humanistic geography thereby, its approach has, however, been criticized on more than one grounds as below. Beginning in the 1980s, humanistic research faced increasing criticism from quantitative analytic geographers, on the one hand; and Marxist, feminist, and post-structural geographers, on the other hand (Cloke, Philo, \& Sadler, 1991; Cresswell, 2013).

Quantitative geographers largely criticized humanistic work in relation to research method. In turning away from deductive theory, pre-defined concepts, and measurable validation, how could humanistic geographers be certain that their interpretive conclusions were accurate, comprehensive, and trustworthy? In response, humanistic geographers emphasized that their approach was generally inductive in that it drew on the richness and complexity of human situations and events to locate generalizable descriptions and theories. Humanistic geographers pointed out that the conclusions of any humanistic study were no more or no less than interpretive 
possibilities open to the public scrutiny of other interested parties. Theyemphasized that their interpretive sources were wide-ranging and included field notes, focus groups, autobiographical descriptions, accounts from participant-observation, and material texts like photographs, films, buildings, landscapes, imaginative literature, and archival documents. One methodological device used by humanistic geographers to better assure accuracy and trustworthiness was triangulation, whereby researcher drew on multiple modes of evidence gathering methods to identify different lived perspectives and to corroborate different information sources.

The criticisms of feminist, Marxist, and post-structural geographers emphasized conceptual, ideological, and ethical concerns. Feminist geographers claimed that humanistic research was essentialist in uncritically assuming an unchanging, universal human condition that ignored individual and group diversity, including gender, social, cultural, and economic differences. These feminist geographers argued that humanistic work was authoritative in that it appeared to privilege the interpretive powers of scholarly experts who arbitrarily claimed the status to identify and describe the geographical situations of "more ordinary" people. Feminist critics contended that humanistic work presupposed an implicit masculinist bias that assumed academically trained men (mostly) could understand all others' situations; for example, the experiences of women, the less able, gays and lesbians, ethnic and racial communities, and so forth. Marxist geographers criticized humanistic geography because they saw it as voluntarist in that it uncritically interpreted social life as a function of intentional, willed plans and actions of individuals. The Marxist claim was that humanistic thinking gave too much weight to the autonomous human agency at the expense of entrenched, transparent social structures and power relations. Marxist critics pointed out that humanistic geographers gave little attention to the underlying economic and political dynamics shaping places and peoples' everyday lives.

Humanistic geographers responded to the essentialist, authoritative, and masculinist charges by arguing that, in fact, humanistic work recognized human differences and sought conceptual and methodological ways for thoroughly engaging with the uniqueness of individuals and groups. They pointed to studies that used participantobservation and other qualitative methods to understand particular geographical situations. For example, David Ley's work on of how African-Americans negotiated their lives in the place context of Philadelphia's inner city. In regard to the Marxist charge that they neglected the role of societal structures in constraining human freedom, humanistic geographers responded that their perspective could examine phenomena such as power, exclusion, resistance, and conflict, though little work was done in this direction, partly ||132 || 
perhaps because most humanistic geographers instinctively favored freedom, creativity, and personal and group autonomy. Humanistic geographers accepted the Marxist claim that structural conditions are critical for understanding human action but, equally important, they argued, was the role of peoples' values, beliefs, worldviews, intentions, and taken-for-granted ways of coping with the world. Humanistic geographers focusing on interpretations of social worlds probed the structural constraints of places and social worlds directly but gave equal weight to human agents' being aware of and being able to change their life ways in relation to limiting social and economic structures.

Post-structural geographers questioned humanistic work in yet other ways. Some post-structural critics claimed that humanistic geographers ethically favored place, insideness, and rootedness over non-place, outsideness, and mobility; place itself was assumed to be centered, static, bounded, and exclusionary. Instead, poststructural critics spoke of a "progressive sense of place" and focused on how places relate and respond to their wider social and environmental contexts. For these critics, places held their importance geographically, but the crucial theoretical and practical aim was finding ways whereby places could better incorporate diversity and partake in constructive interconnections and exchanges with other places. Another group of poststructural critics questioned whether "place" even existed in the postmodern world, claiming that real world places were becoming marginal and obsolete because of trends toward globalization, non-places, and hyperspace. Some post-structural critics went so far as to suggest that, in our proliferating 'hyper-real' world of digital environments and virtual realities, the lived distinctions between 'real' and 'imagined' places should be critically called into question. These critics challenged the rigid, unchanging stasis of physical places and environments that they claimed humanistic accounts encompassed. These critics spoke instead of provisional, shifting connections and flows among people, spaces, places, nation-states, information, worldviews, and digital representations. Key themes were mobility, flux, hybridity, relativity, relationality, discontinuities, rhizomes, assemblages, hyper-worlds, virtual places, and smooth and striated spaces.

Humanistic geographers responded to these post-structural criticisms by suggesting that, even as globalization eroded some places, it strengthened other places and contributed to new kinds of places. Humanistic geographers pointed out that, even with the growing importance of digital communication, hyperspace, and virtual realities, real places retain their importance because people are bodily beings who always unavoidably live a life in some physical place. This inescapable embodiment-in-place was often ignored by the post-structural critics who aimed for a more progressive sense of place grounded in a dynamic, ever-shifting network of intertwined, porous places. 
Humanistic geographers contended that a good portion of such dynamic exchange remains grounded in the habitual regularity of emplaced bodies. Humanistic geographers also emphasized that any dynamic interchange among places presupposes a robust integrity of each place itself; this robust integrity is at least partly founded in the habitual regularity of lived bodies inescapably bound to a physical place (Seamon, 2013).

\section{Humanistic geography at the turn of the new millennium}

Though humanistic geography as an explicit subfield largely disappeared by the early 1990s, interest in humanistic themes continued inside and outside the discipline, particularly on the part of phenomenological philosophers concerned with the phenomenon of place. Humanistic geographers' interpretations of place in the 1970 s were largely subjectivist in that place was understood as a cognitive or affective representation inside the human being and ontologically separate from the objective environment outside. As phenomenological philosophers Edward (2009) and Jeff Malpas (1999) probed the topic in the 1990s and 2000s, they argued that place is a primary ontological structure that encompasses both human experience and the physical world in which that experience unfolds. This argument that human being is always human-being-in-place highlighted an important new way of geographical thinking because it claimed that place is necessarily an integral, inescapable contributor to human existence and life. This understanding meant that places are not material environments existentially apart from the people associated with them but, rather, the holistic unit of human-beingsexperiencing place.

Prominent geographers, Anne Buttimer's "Sustainable Landscapes and Lifeways" (2001); Robert David Sack's "A Geographical Guide to the Real and the Good" (2003); Edmunds Valdemars Bunkse's "Geography and the Art of Life" (2004); and Yi$\mathrm{Fu}$ Tuan's "Humanistic Geography" (2012) were the milestone of the development of humanistic approaches in geography. Sometimes called lived emplacement or embodied place, this phenomenon was understood to be complex, dynamic, and incorporating generative processes via which a place and its experiences and meanings shift or remain the same (Seamon, 2013).

Partly because of Casey and Malpas's writings, researchers inside and outside geography brought renewed scholarly attention to the lived qualities of place and to other topics associated with the humanistic tradition. For example, geographers Soren Larsen \& Jay Johnson (2012) worked to link a place-grounded ontology ${ }^{8}$ with affinity 
Kanhaiya Sapkota / The Geographical Journal of Nepal Vol. 10: 121-140, 2017

politics, and geographer Sara Johansson (2013) developed a method of "rhythm analysis" to understand how the "lived body" encompasses and is encompassed by the urban environment as experienced. Echoing earlier claims on lived embodiment by French phenomenologist Maurice Merleau-Ponty, Johansson argued that the bodily dimensions of environmental experience are as meaningful and as important in understanding the place as environmental cognition and intellectual geographic knowledge.

We also find a continuing body of work involving a humanistic approach to geographical and environmental topics in research by non-geographers. One example is philosopher Ingrid Stefanovic's efforts toward a phenomenology of sustainability via an examination of how place and lived emplacement provide a foothold for grounding environmental responsibilities and actions in relation to particular individuals, groups, and localities (Stefanovic, 2000). A second example is the research of literary scholar Anna Westerståhl Stenport, who drew largely on Swedish writer August Strindberg's works relating to Paris and Stockholm to examine how the nineteenth-century city shaped imaginative literature and how, in turn, that literature shaped perceptions of the nineteenth-century city (Stenport, 2004). A third example is ethnographer Urzula Woźniak's (2009) examination of at homeness and placelessness in the context of current global migration. Drawing on Ukrainian, Turkish, and Vietnamese examples, she used the concept of community attachment to understand the contrasting degree of identification that different immigrant groups feel for their place of relocation; she demonstrated how mental associations with immigrants' original home place play a significant role in their understanding of and feelings toward their new place of residence.

These studies exemplify a new generation of researchers who are interested in such humanistic topics as place experience, at homeness, community involvement and identity, out-of-place-ness, environmental personhood, lived emplacement, mobility and place, supportive or undermining processes shaping place, and the lived similarities and differences between real places and virtual places (Seamon, 2013). All these works remain grounded in a central humanistic aim as to bring "human beings in all of their complexity to the center-stage of human geography" (Cloke, Philo, \& Sadler, 1991, p. $58)$.

Most generally, however, the perspective of humanistic geography largely fell from sight or metamorphosed into the "new cultural geography" molded from poststructuralist, feminist, and critical perspectives. In this regard, many human geographers shifted their attention to the cutting-edge work of philosophers Michel Foucault, Jacques Derrida, Gilles Deleuze, Félix Guattari, Bruno Latour, and another poststructuralist, critical, and relationalist theorists (Cresswell, 2013). One example of 
how humanistic themes shifted in the new millennium is Textures of Place (Adams, Hoelscher, \& Till, 2001) an edited collection dedicated to Yi-Fu Tuan and the humanistic tradition. Overall, the volume's twenty-seven chapters demonstrated how an engagement with critical social theory worked to transform earlier humanistic understandings of place, environmental experience, and geographical meaning. The editors of the volume called for a reconsideration of humanistic geography in the context of "revised assumptions about human subjectivity, the transparency of language, and the use of descriptive categories based upon Western traditions of understanding"(Adams, Hoelscher, \& Till, 2001, p. xvii).

\section{New direction in humanistic geography}

Following humanistic geography's turnand even during the turna variety of up-andcoming research agendas continue to arise, all centered on how human actions take place, how humans practice and interact with their place in space, and how humans move and interpret their place in space. These endeavors encompass psychoanalytic theory, performativity, feminist theory, space-time convergence, and increased interaction between physical and human geography, with specific attention paid to the individual's role in influencing his or her perception of place in the physical landscape. Of these, performativity and feminist theory have been extremely influential, although an often veiled attempt has been made in the humanistic physical geography realm. On humanistic geography's future, perhaps Massey (2005) conveys the most comprehensive approach, tackling epistemological and ontological issues related to space, place, and people in a fairly straightforward, but often heady, manner, such as explaining that space is time and space is place and further arguing that space is foundational to every person's well-being. Although Pile (1996) uses the city as its stage and evaluates the role that psychoanalysis plays in a person's creation of space, it also uses ethnography as a way in which to portray how researchers might better understand individual behavior in regard to place and space creation. In a series of essays spanning roughly a decade, (Harvey, 1979) suggests that the cyborg, as an entity, exists beyond gender and that this line of thinking may create huge opportunities for women by breaking away from traditional dialectic/dualistic models, whereas Buttler(1990) outlines the social norms and ideas surrounding gender differences, expanding theoretical underpinnings of feminist geography (and feminist theory in general). Meanwhile, Allen (2011) uses actor-network-theory to advocate for bridging the human-physical geography divides through individual interpretation of a given landscape, noting the inherent connections already available between the physical and human landscapes.

Finally, the humanistic geography achieves an understanding of the human world by studying people's relations with nature, their behavior as well as their feelings 
and ideas with regards to space and place. The humanist approach is 'methodologically obscure'. The goals of understanding man's meaningful experience and knowledge seem to lead to a situation in which any method is acceptable. It isa philosophy that involves thinking rather than practical activity. Its methodology is eclectic and sources of interpretation are numerous and therefore it takes the stance of multiple realities. The application of humanistic approach in geography is emerging in the Nepalese context since the beginning of 90s. For long time Nepalese geographers followed the Western Eurocentric view and appear to be content in following western notions and ignored understanding our own social and cultural aspects/landscapes that enrich our knowledge of geography(Subedi, 2014). Therefore, there is a need to rethink our research practices towards better understanding of the world we live in from our own eyes with philosophical and methodological rigor. Humanistic approach is one way forward in this direction.

\section{Endnotes}

1 Humanistic geography is a term used by Yi-Fu Tuan geographies based on the methods of the humanities that strive to synthesize subjective and objective studies and that lay particular importance on human creativity. For more details please see, Gregory, D.; Johnston, R.; Pratt, G.; Watts, M. \&Whitemore, S. (2009). The dictionary of human geography. WestSussex: Willey-Blackwell, pp. 356-358).

2 Space is a central concept in geography, used in the form of absolute, relative and relational space. It also contents spatial analysis, spatial diffusion, spatial exclusion, spatial factor and spatial science. For more details please see, Gregory, D.; Johnston, R.; Pratt, G.; Watts, M. \&Whitemore, S. (2009). The dictionary of human geography. West-Sussex: WilleyBlackwell, pp. 707-710).

3 Place is a portion of geographical space. Sometimes defined as 'territories of meaning' or 'a node of activities.' In a generic sense, a place is a geographical locale of any size or configuration, comparable to equally generic meanings of area, region or location. In human geography and the humanities more generally, however, place is often attributed with greater significance (cf. landscape). It is sometimes defined as a human-wrought transformation of a part of the Earth's surface or of preexisting, undifferentiated space. For more details please see, Gregory, D.; Johnston, R.; Pratt, G.; Watts, M. \&Whitemore, S. (2009). The dictionary of human geography. West-Sussex: Willey-Blackwell, pp. 539-540).

4 Landscape geography refers to the study of cultural and natural landscpaes, their particular features and their evolution. It is used in different dimensions of the explanations, i.e. landscape chronology, landscape ecology, landscape morphology and landscape geography (Holt-Jensen, 2006). For more details please see, Gregory, D.; Johnston, R.; Pratt, G.; Watts, M. \&Whitemore, S. (2009). The dictionary of human geography. West-Sussex: WilleyBlackwell, pp. 409-411).

5 Region is a distinct segment of the earth that, in the traditional sense of the world, has developed a particular character through a long process of interaction between humanity and 
Kanhaiya Sapkota / The Geographical Journal of Nepal Vol. 10: 121-140, 2017

nature (vertical connections). Regions have also been defined on the basis of interactions between centers and hinterlands (horizontal connections) (Holt-Jensen, 2006). For more details please see, Gregory, D.; Johnston, R.; Pratt, G.; Watts, M. \&Whitemore, S. (2009). The dictionary of human geography. West-Sussex: Willey-Blackwell, pp. 630-632).

6 For more details please see, Gregory, D.; Johnston, R.; Pratt, G.; Watts, M. \&Whitemore, S. (2009). The dictionary of human geography. West-Sussex: Willey-Blackwell, pp. 676677).

7 Epistemologyis the application and development of knowledge; a theory of knowledge that seeks to determine correspondence between the realm of knowledge (concepts, propositions) and the realm of objects (experiences, things). An epistemology guides the formulation of research problems (Holt-Jensen, 2006). For more details please see, Gregory, D.; Johnston, R.; Pratt, G.; Watts, M. \& Whitemore, S. (2009). The dictionary of human geography. WestSusses: Willey-Blackwell, pp. 206-208.

8. Ontology is the theory of being and the nature of existence. Empiricism and realism may be regarded as two ontological traditions. For more details please see, Gregory, D.; Johnston, R.; Pratt, G.; Watts, M. \&Whitemore, S. (2009). The dictionary of human geography. WestSussex: Willey-Blackwell, pp. 511-512).

\section{References:}

Adams, P. C., Hoelscher, S., \& Till, K. E. (2001). Textures of place: Exploring humanist geographies. Minneapolis: University of Minnesota Press.

Allen, C. D. (2011). On actor-network theory and landscape. Area, 43(3), 274-280.

Bunkse, E. (2004). Geography and the art of life. Baltimore, Maryland: Johns Hopkins University Press.

Buttimer, A. (2001). Sustainable landscapes and lifeways: Scale and appropriateness. Cork: Cork University Press.

Buttler, J. (1990). Gender and trouble. London: Routledge.

Casey, E. S. (2009). Getting back into place. Bloomington, Indiana: Indiana University Press.

Cloke, P., Philo, C., \& Sadler, D. (1991). Approaching human geography: An introduction to contemporary theoretical debates. London: SAGE.

Cresswell, T. ( 2013). Geographic Thought: A Critical Introduction. Oxford: WileyBlackwell.

Diggins, J. (1977). Reification and the cultural hegemony of capitalism. Social Research, 44, 354-383. 
Kanhaiya Sapkota / The Geographical Journal of Nepal Vol. 10: 121-140, 2017

Duncan, J. (1978). The social construction of unreality: an interactionist approach to the tourist's cognition of environment . In D. a. Ley, Humanistic geography: prospects and problems (pp. 269-282). Chicago: Maaroufa Press.

Godkin, M. (1977). Space, time and place in the human experience of stress. Canada: School of Geography, Clark University.

Harvey, D. (1969). Explanation in geography. London: Edward rnold.

Harvey, D. (1979). Monument and myth. Annals of the Association of American Geographers, 69: 362-381.

Hirsch, F. (1977). Social limits to growth. London: Routledge and Kegan Paul.

Holt-Jensen, A. (2006). Geography: History and concepts: A student's guide. London: Sage Publication.

Jackson, J.B. (1995). A sense of place, a sense of time. Design Quarterly, 164, pp. 2427

Johansson, S. (2013 ). The rhythm lives in my steps: A rhythm-analytical study of body, city and knowledge. Uppasala: Uppsala University.

Johnston, R. (1984). The World is Our Oyster. Transactions of the Institute of British Geographers, 9 (4): 443-459.

Johnston, R. J. (1979). Geography and geographers: Anglo-American human geography since 1945. New York: Edward Arnold.

Larsen, S., \& Johnson, J. (2012). Toward an open sense of place: phenomenology, affinity, and the question of being. Annals of the Association of American Geographers, 102 (3): 632-646.

Leiss, W. (1978). The limits to satisfaction. London: Marion Boyars.

Ley, D. (1980 ). Power and the geographical lifeworld. Ottawa: Society for Phenomenology and Existential Philosophy.

Ley, D., \& Samuels, M. S. (1978). Humanistic geography: Prospects and problems. Chicago: Maaroufa Press.

Lofland, J. (1971). Analyzing social settings: A guide to qualitative observation and analysis. Belmont Calf: Wadsworth.

Malpas, J. (1999). Place and Experience. . Cambridge: Cambridge University Press.

Mannheim, K. (1952). Essays on the sociology of knowledge. London: Routledge \& Kegan Paul.

Massey, D. (1999). Space-time, 'science' and the relationship between physical geography and human geography. Transactions of the Institute of British Geographers, 24 (3): 261-276. 
Kanhaiya Sapkota / The Geographical Journal of Nepal Vol. 10: 121-140, 2017

Massey, D. (2005). For space. London, New Delhi: SAGE.

Pile, S. (1996). The body and the city: Psychoanalysis, space and subjectivity. London: Blackwell Publishing Ltd.

Pocock, D. C. (1983). Geographical fieldwork. Geography, 68: 319-325.

Relph, E. (1976). Place and Placelessness. London: Pion.

Relph, E. (1981). Rational Landscapes and Humanistic Geography. New York: Barnes and Noble.

Rubin, B. (1979). Aesthetic ideology and urban design. Annals of the Association of American Geographers, 69: 339-361.

Sack, R. D. (2003). A geographical guide to the real and the good. London: Routledge.

Saunders, P. (1979). Urban politics: a sociological interpretation. London: Hutchinson.

Schutz, A. (1970). Phenomenology and social relations. Chicago: University of Chicago Press.

Seamon, D. (2013). Lived bodies, place, and phenomenology: Implications for human rights and environmental justice. Journal of Human Rights and the Environment, 4: 143-166.

Stefanovic, I. L. (2000). Safeguarding Our Common Future: Rethinking Sustainable Development. Albany, New York: State University of New York Press.

Stenport, A. W. (2004). Making space: Stockholm, Paris and the urban prose of Strindberg and his Contemporaries. Berkeley: University of California Press.

Subedi, B. P. (2014). The state of geography teaching and research in Nepal: A review and reflection. Kathmandu: Martin chautari.

Subedi, B. P. (1993). Continuity and change in population movement: From inside a rural Nepali community.An Arbor, Michigan: UMI.Dissertation services.

Thompson, E. (1978). The poverty of theory . London: Merlin Press.

Tuan, Y.-F. (1974). Topophilia. Englewood cliffs. New Jersey: Prentice-Hall.

Tuan, Y.-F. (1976). Humanistic Geography. Annals of the Association of American Geographers, 66: 266- 276.

Tuan, Y.-F. (2012). Humanistic geography. New York: George F. Thompson Publishing.

Williams, R. (1977 ). Marxism and literature. Oxford: Oxford University Press.

Woźniak, U. (2009). Not as colorful as Ukrainian villages, but nearly as lively as Hanoi. In J. Holten, \& L. M. Simenstad, You are here (pp. 174-199). Berlin: Broken Dimanche Press. 